\title{
Information about Electronic Governance: A Tool to Curb Corruption in Nigeria
}

\section{Informasi tentang Tata Kelola Elektronik: Alat untuk Mengatasi Korupsi di Nigeria}

\author{
Rasheed Gbenga Jimoh ${ }^{1}$, O. B. Longe ${ }^{2}$, Ndunagu J. N. ${ }^{3}$ \\ ${ }^{1}$ Department of Computer Science, Faculty of Communication and Information \\ Sciences, University of Ilorin, Ilorin, Nigeria \\ ${ }^{2}$ Department of Computer Science, Caleb University, Imota, Lagos, Nigeria \\ ${ }^{3}$ National Open University of Nigeria, University Village Plot 91, Cadastral Zone, \\ Nnamdi Azikiwe Expressway, Abuja, Nigeria \\ *Corresponding author, e-mail: jimoh_rasheed@yahoo.com
}

\begin{abstract}
Corruption has been declared to be the cause of poverty and poor standard of living in the Nigeria. This is caused by lack of accountability and transparency in the Government sector, mostly aided by manual accounting system and ordinary paper document in the operation of the sector. Sequel to the evolution of Information and Communication Technology, electronics governance was implemented in Nigeria. Therefore, this study examines the role of electronic governance as a tool for curbing corruption in Nigeria. As such, a survey instrument were administered to 240 civil servants from different public sectors in Nigeria. The findings revealed that, implementation of e-governance has helped to curb corruption in Nigeria and also played a great role in improving efficiency of Nigeria economy. Also this study found that, the need to embrace electronics governance given the phobia exhibited by many Nigerian populace and workforce as to the use of electronics governance.

Keywords: Corruption, E-Governance, Implementation, Information and Communication Technology.

Abstrak

Korupsi telah dinyatakan sebagai penyebab kemiskinan dan standar hidup yang buruk bagi penduduk Nigeria. Hal ini disebabkan oleh kurangnya akuntabilitas dan transparansi di sektor Pemerintah, sebagian besar dibantu oleh sistem akuntansi manual dan dokumen kertas biasa dalam operasi sektor ini. Sekuel dengan evolusi Teknologi Informasi dan Komunikasi, tata kelola elektronik telah dilaksanakan di Nigeria. Oleh karena itu, penelitian ini menguji peran tata kelola elektronik sebagai alat untuk mengendalikan korupsi di Nigeria. Dengan demikian, instrumen survei diberikan kepada 240 pegawai negeri dari berbagai sektor publik di Nigeria. Temuan mengungkapkan bahwa, penerapan e-governance telah membantu untuk mengekang korupsi di Nigeria dan juga memainkan peran besar dalam meningkatkan efisiensi perekonomian Nigeria. Juga penelitian ini menemukan bahwa, kebutuhan untuk merangkul tata kelola elektronik telah memberikan fobia yang ditunjukkan oleh banyak penduduk Nigeria dan tenaga kerja selama menggunakan tata kelola elektronik ini.
\end{abstract}

Kata Kunci: Korupsi, E-Governance, Implementasi, Teknologi Informasi dan Komunikasi.

Copyright (C) 2018 Universitas Semarang. All rights reserved. 


\section{Introduction}

Corruption has eaten so deep into Nigeria that its practice is seen more like a societal norm than an exception. Corruption not only distorts competition but it hinders economic growth and endangers the stability of democratic institutions (Editorial, 2007). The World Bank has specified corruption as among the greatest obstacles to economic and social development Undermines development by distorting the rule of law and weakening the institutional foundation on which economic growth depends. The negative effects of corruption are quite severe on the poor, who are the hardest hit by economic decline, are most reliant on the provision of public goods and services, often unable to pay the extra costs associated with bribery, fraud, and the misappropriation of economic privileges (World Bank, 1997).

Before the advent of e-governance in Nigeria, understanding the real workforce in the three tiers of authorities (Federal, State, and Local Governments) was a mystery and hard like rocket science (Augustine, Sebastine, \& Oliver, 2015). Personnel in Administration in league with their colleagues in Finance inflate the workforce with ghost workers running into hundreds of thousands. And perpetrators of such crime created a system where most staffs are not paid in the banks using workers functioning accounts, they pay cash using their ministries cashiers (Dahida \& Akangbe, 2013). The amount oozing through this channel into the pockets of these fraudsters surpasses the real salary bills government pay to workers. Successive governments battled with this menace through setting up special staff audit committees and what they called "TABLE $P A Y M E N T$ " and physical appearance of staff without getting to the root of the matter (Adeyemo, 2013).

Electronic governance (e-governance) in terms of Integrated Payroll and Personnel Information System (IPPIS), Prepaid Meter, Biometric Time and Attendance, Treasury Single Account (TSA), Electronic Registration, Electronics Payment are ways to restrict corruption, as most of the public sectors do not engage in the practice of egovernance yet. For the purpose of this paper, the definition of e-governance provided in the European Commission (2003) will be adopted: "[e-governance is] the use of information and communication technologies in public administrations combined with organizational change and new skills in order to improve public services and democratic processes and strengthen support to public policies."

The aim of e-governance is to allow the public to initiate a request for a particular government service without going to a government office or having direct contact with a government employee. The service is delivered through government web sites (Rotimi, Obasaju, Lawal, \& Olorunkanmi, 2013). E-governance comprises of an alignment of ICT infrastructures, institutional reform, business processes and service content towards provision of high-quality and value added services to the citizens and businesses (Oye, 2013). The benefits of e-governance come in different forms. Some relate to the provision of fast, inexpensive services to the population (Heeks, 2004) and for socioeconomic development and political reformations for developing countries (Ifinedo \& Uwadia, 2005).

The potential benefits of e-governance that accrue from the use of IT according to Shatne (Shatne, 2001) and Symonds (Symonds, 2000) include: reduced government spending and increased interest earning. Costs incurred by a government in providing services can be reduced by the use of the Internet, reduction in the number of persons in government contacts. Governments are under pressure to meet rising expectations for their service. With the use of the Internet more individuals are able to access the 
government's services without necessarily going to the government office or contacting by telephone. The use of the Internet will reduce the negative attitude individuals have toward government agencies because not many people enjoy interacting with their government, Delivery of government services from any place to citizens 24 hours a day, 7 days a week (Ogunro \& Tolu, 2012). Websites serve as convenient and cost effective platforms for centralized service provision. Businesses, residents, visitors, and intergovernmental agencies can easily access public information related to their specific needs by simply checking on different web links. They can also contact government officers directly through email or online request forms (Nageri, Gunu, \& Abdul, 2013).

However, e-governance has the potential to alter the traditional relationship between government and citizens by creating a new virtual government-and-citizen interface (Nwankwo, 2014). Information Communication and Technology is often one of the most important components in minimizing corruption in service delivery and enhancing transparency (Bhatnagar, 2003). Given the fact that a large number of countries have ambition for using ICT in service delivery under the title ' $e$ governance,' there is a significant opportunity to impact corruption by designing these systems in a manner that can take away the basic reason that enables corruption to take place and for transparency (Davies \& Fumega, 2014). Therefore, this paper examines the role of Electronic Governance as a tool for curbing corruption. The followings are the specifics objectives of the study were to:

1. determine the implementation status of electronic governance in Nigeria.

2. determine people's awareness of its implementation in Nigeria.

3. determine the effect of its implementation in curbing corruption in Nigeria.

\section{Methodology}

The instrument used for data collection for this study was the questionnaire method. This was because of the nature of information required and the form of analysis to be conducted. A 16-question structured questionnaire was designed and administered to Civil servants from different public sectors. The questionnaires were designed in anonymity to enable the civil servants fill them with greater degree of honesty without fear of intrusion of privacy. Of the 350 questionnaires administered, 240 were returned adequately filled.

Data collected were statistically analyzed using descriptive statistics like response, percentages, and graphs. The null hypothesis involved in the study was tested using chisquare. Among the 240 questionnaires filled, 153 respondents $(64 \%)$ were male while $87(36 \%)$ were females. Of the respondents, the majorities; 67\%, were between 25 and 45 years old, while $33 \%$ were 46 to 65 years old. Out of the 240 respondents, $216(90 \%)$ respondents are aware of the implementation of e-governance in Nigeria while $16(10 \%)$ are not aware. Below are the analyses.

\section{Result and Discussion}

Research question 1. Is there corruption in Nigeria?

From table 1 and figure 1, the result of the investigation showed that 240 civil servants responded, of this total, 216 respondents representing $93 \%$ indicated that there is corruption in Nigeria, while, 24 respondents representing $7 \%$ indicated that there is no corruption in Nigeria. 


\begin{tabular}{|c|c|c|}
\hline Is there corruption in Nigeria? & Response & Percentage (\%) \\
\hline Yes & 223 & 93 \\
\hline No & 17 & 7 \\
\hline Total & 240 & 100 \\
\hline
\end{tabular}

Table 1. Response to if there is Corruption in Nigeria

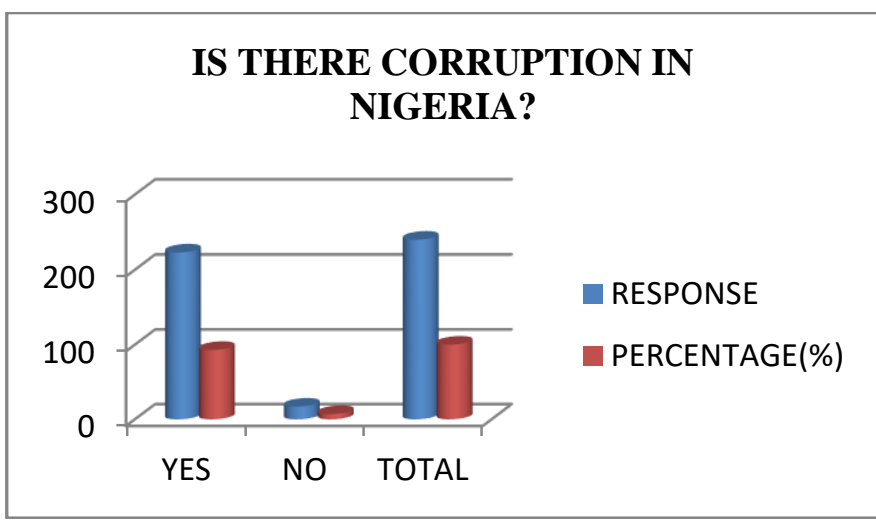

Figure 1. Column chart Showing the Response if there is Corruption in Nigeria Research question 2. What are the different forms of corruptions that are common in public sectors?

Figure 2 shows that $12 \%$ of the respondents said Extortion of money from motorists on the road by police men is a common form of corruptions in public sectors, $10 \%$ of the respondents said Power Holding Company of Nigeria (PHCN) gives bills that are not in line with meter readings, $24 \%$ of the respondents said during Independent National Electoral Commission (INEC) elections there was alteration of voters results in favour of a candidate of their choice, $40 \%$ of the respondents stated that in Civil service cases of ghost workers deliberately introduced by top government officials are dominant, $14 \%$ of the respondents said in the Education sectors Falsification of result and other data is common.

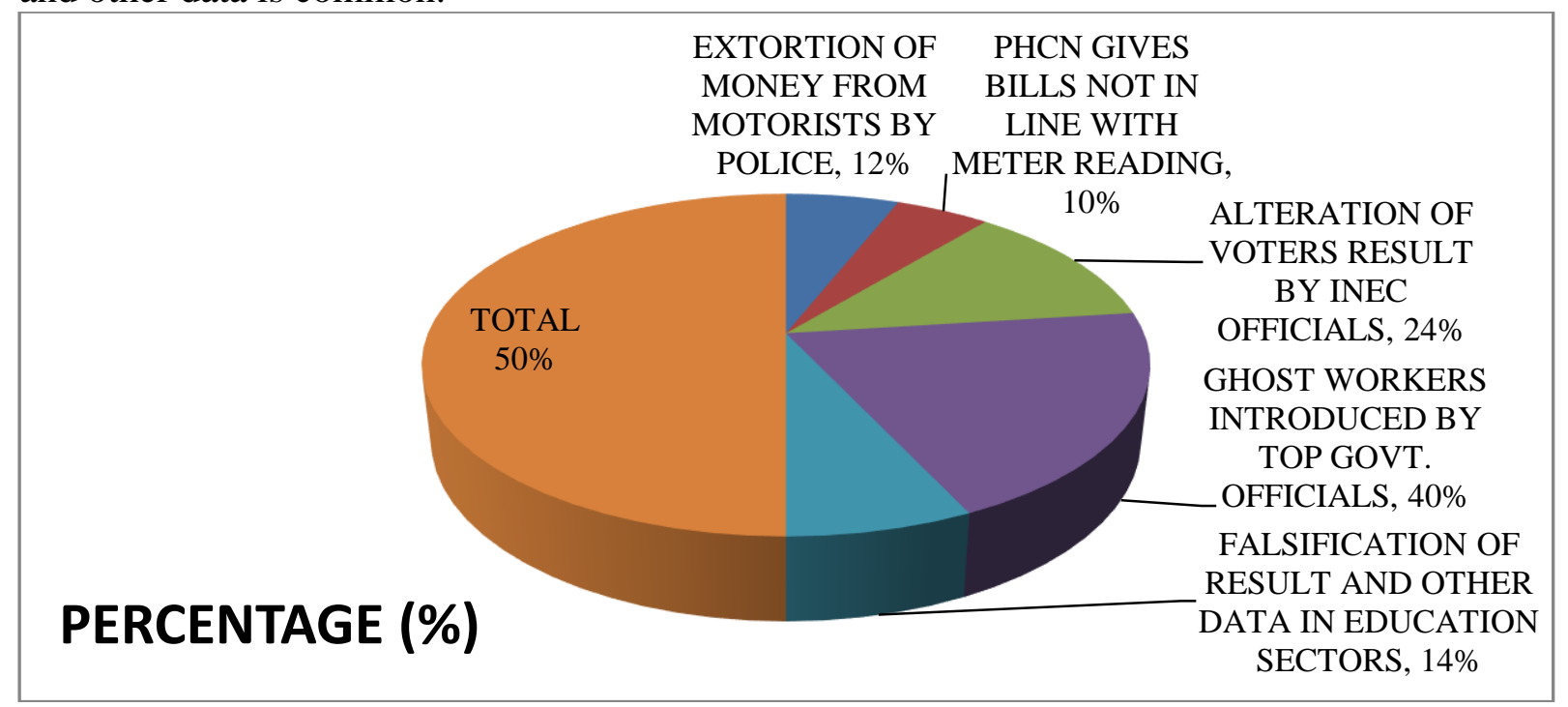

Figure 2. Pie Chart Representation of Different Forms of Corruptions that are Common in Public Sectors 
Research question 3. Are you aware of the implementation of e-governance in Nigeria? Table 2 shows that 216 respondents representing $90 \%$ are aware of implementation of the e-governance in Nigeria, while 24 respondents representing $10 \%$ are not aware of egovernance. This shows that most civil servants are aware of the implementation of egovernance in Nigeria.

\begin{tabular}{|c|c|c|}
\hline $\begin{array}{c}\text { Are you aware of the Implementation of E-Governance } \\
\text { in Nigeria? }\end{array}$ & Response & Percentage (\%) \\
\hline Yes & 216 & 90 \\
\hline No & 24 & 10 \\
\hline Total & 240 & 100 \\
\hline
\end{tabular}

Table2. Response to if they are aware of the Implementation of e-governance in Nigeria Research question 4. Can e-governance be used to control corruption?

Table 3 and figure 4 show that 192 respondents representing $89 \%$ agreed it can be used to control corruption, while 24 respondent representing $11 \%$ disagreed. This shows that e-governance can be used to control corruption in Nigeria.

\begin{tabular}{|c|c|c|}
\hline Can e-governance be used to Control Corruption? & Response & Percentage (\%) \\
\hline Yes & 192 & 89 \\
\hline No & 24 & 11 \\
\hline Total & 216 & 100 \\
\hline
\end{tabular}

Table 3. Response to if e-governance can be used to Control Corruption Research hypothesis

$\mathrm{H}_{0}$ : The Implementation of e-governance has not helped to curb corruption in Nigeria and does not play a great role in improving efficiency of Nigeria economy.

$\mathrm{H}_{1}$ : The Implementation of e-governance has helped to curb corruption in Nigeria and also play a great role in improving efficiency of Nigeria economy.

Test of Hypothesis

$\mathrm{X}^{2}$ cal $15.84>\mathrm{X}^{2}$ tab that is $\mathrm{H}_{0}>\mathrm{H}_{1}$, we reject $\mathrm{H}_{0}$ and accept $\mathrm{H}_{1}$. Therefore, we accept the Alternative hypothesis and reject the Null hypothesis. This means that the implementation of e-governance has helped to curb corruption and improved the economy of Nigeria.

\begin{tabular}{|l|l|l|l|}
\hline & Yes & No & Total \\
\hline 1 & 216 & 24 & 240 \\
\hline 2 & 199 & 17 & 216 \\
\hline 3 & 204 & 36 & 240 \\
\hline 4 & 201 & 39 & 240 \\
\hline 5 & 213 & 45 & 240 \\
\hline 6 & 205 & 35 & 240 \\
\hline Total & 1220 & 196 & 1416 \\
\hline
\end{tabular}

Table 4. Variables of Response of the Hypothesis Test

\begin{tabular}{|l|l|l|l|l|l|}
\hline & $\begin{array}{l}\text { OBSERVED } \\
(\mathrm{O})\end{array}$ & $\begin{array}{l}\text { EXPECTED } \\
(\mathrm{E})\end{array}$ & $|\mathrm{O}-\mathrm{E}|$ & $(\mathrm{O}-\mathrm{E})^{2}$ & $(\mathrm{O}-\mathrm{E})^{2} / \mathrm{E}$ \\
\hline 1 & 216 & 206.78 & 9.22 & 85.01 & 0.41 \\
\hline 2 & 24 & 33.22 & -9.22 & 85.01 & 2.56 \\
\hline 3 & 199 & 186.10 & 12.9 & 166.41 & 0.89 \\
\hline 4 & 17 & 29.90 & -12.9 & 166.41 & 5.57 \\
\hline 5 & 204 & 206.78 & -2.78 & 7.73 & 0.04 \\
\hline 6 & 36 & 33.22 & 2.78 & 7.73 & 0.23 \\
\hline 7 & 201 & 206.78 & -5.78 & 33.41 & 0.16 \\
\hline
\end{tabular}




\begin{tabular}{|l|l|l|l|l|l|}
\hline 8 & 39 & 33.22 & 5.78 & 33.41 & 1.01 \\
\hline 9 & 195 & 206.78 & -11.78 & 138.77 & 0.67 \\
\hline 10 & 45 & 33.22 & 11.78 & 138.77 & 4.18 \\
\hline 11 & 205 & 206.78 & -1.78 & 3.17 & 0.02 \\
\hline 12 & 35 & 33.22 & 1.78 & 3.17 & 0.10 \\
\hline Total & & & & & 15.84 \\
\hline
\end{tabular}

Table 5. Chi-square Distribution

$\chi 2=$ chi- square value, $\mathrm{O}=$ observed value, $\mathrm{E}=$ expected value

chi Square $(\chi 2)=15.84$

Degree of freedom $(\mathrm{df})=(\mathrm{R}-1)(\mathrm{C}-1), \mathrm{Df}=(6-1)(2-1)=5$,

Using 5\% level of significant

$\mathrm{X}^{2} \mathrm{tab}=11.070$

$\mathrm{X}^{2} \mathrm{cal}=15.84$

The finding of the study tested a hypothesis that the implementation of egovernance has helped to curb corruption in Nigeria and improved the economy of Nigeria. The result obtained in this study supports the deductions of Adeyemo (Adeyemo, 2013) and (Danfulani, 2013). Which reveal that e-governance has helped to reduce corruption and improve the economy Nigeria. Therefore, it is clear that implementation of e-government not only saves resources, effort and money but it can also extensively increase service quality levels, minimize financial misappropriation, falsification of records, non-remittance of tax or money collected (Bhatnagar, 2003).

E-governance have helped to improves efficiency of government agencies in processing of data and build trust between governments and citizens, an Essential factor in good governance by using internet-based strategies to involve citizens by ensuring that the public has effective access to information and contribute to decision making processes (Ndou, 2004). The introduction of the 'Biometric Time and Attendance' has helped to regularize the civil service or public sector as this has greatly reduce if not put to an end the falsification of attendance and time of arrival to work, help the government take note of the actual number of staff it has thereby eliminating ghost workers and helping government saves huge sums of money that is being paid ghost workers (Ekomwenrenren \& Ekuobase, 2015).

The e-government applications and electronic payments can help to eliminate the need for participation of government officials, which thus results in a reduction in the need to pay bribes in order to speed up transactions and access to services. The Joint Admission Matriculation Board (JAMB) has equally been using e-Registration process and in administering examination using Computer Based Test (CBT). This can help considerably in the reduction of malpractices such as impersonation during registration and the examination proper. The Independent National Electoral Commission (INEC) also uses the biometric technology in the voters' registration and accreditation processes. This is believed to have helped to minimize electoral malpractices such as multiple voting and impersonation. The Independent Revenue e-Collection Scheme implemented under Treasury Single Account (TSA) initiative requires that government revenue collection is put into a single account for proper cash management. Treasury Single Account enables governments to establish centralized control over its revenue through effective cash management. It also enhances accountability and how much is accruing to the government is on a daily basis. TSA has helped to tide corruption as the leakages that used to be there in the system where people used money as they want and decide what to return to the government will no more be there (Heeks, 2004). The 
introduction of Integrated Payroll and Personnel Information System (IPPIS) have helped to checkmate the activities of ghost workers in Nigeria therefore saving billions of Naira for the government and it has made the government to ascertain the real work force in the various tiers of government which was not the case prior to the introduction of IPPIS. Also the adoption of e-governance enhances probity, responsibility and stewardship.

\section{Conclusion}

In conclusion, this study has analyzed how electronic governance as a tool curbs corruption and found some elements of how e-governance has helped to minimize corrupt actions. This study has shown that the role of E-Governance as a tool for reducing corruption cannot be underestimated. Consequent upon several revelation from the research conducted, therefore this research recommends that, government should enlighten citizens and its workforce on the need to embrace E-Governance. Additionally, government should strive to ensure that access to its portal should be highly protected via the use of passwords and other ICT measures to checkmate the activities of hackers.

\section{Acknowledgement}

The authors would like to thank to our respondents (240 civil servants from different public sectors in Nigeria).

\section{References}

Adeyemo, A. B. (2013). E-government implementation in Nigeria: An assessment of Nigeria's global e-government ranking. Journal of Internet and Information System, 2(1), 11-19.

Augustine, O. E., Sebastine, A. O., \& Oliver, H. M. (2015). E-Governance and Corruption in Nigeria. International Journal of Multidisciplinary Research and Development, 2(8), 640-645.

Bhatnagar, S. (2003). Transparency and Corruption: Does E-government help? Draft paper for the compilation of CHRI 2003 Report OPEN SESAME: looking for the Right to Information in the Commonwealth. Commonwealth Human Rights Initiative.

Dahida, D. P., \& Akangbe, O. M. (2013). Corruption as a Bane for Under-Development in Nigeria: Issues and Challenges. International Affairs and Global Strategy, $15(2)$.

Danfulani, J. (2013). E-governance: A weapon for the fight against Corruption in Nigeria. Sahara.

Davies, T., \& Fumega, S. (2014). Anti-Corruption Resource Centre. Anti-Corruption Resource Centre, 4(4), 43-48.

Editorial. (2007, February). This Day Newspaper Editorial. This Day Newspaper.

Ekomwenrenren, I., \& Ekuobase, G. (2015). Curbing Corruption in Nigeria Using Service Innovation. A Multidisciplinary Journal Publication of the Faculty of Science, Adeleke University, 2(2), 103-114.

Heeks, R. (2004). E-Government for Development Transparency Definitions Page. Retrieved February 2, 2018, from www.egov4dev.org.

Ifinedo, P., \& Uwadia, C. (2005). Towards E-governance in Nigeria: Shortcomings, Successes, Swish or Sink. In Proceedings of the International Federation of 
Information Processing (IFIP) WG 9.4 Conference (pp. 75-86). Abuja, Nigeria.

Nageri, K. I., Gunu, U., \& Abdul, F. A. (2013). Corruption an Economic Development: Evidence from Nigeria. Kuwait Chapter of Arabian Journal of Business and Management Review, 3(2), 118-123.

Ndou, V. (2004). E-government for developing Countries: Opportunities and Challenges. The Electronic Journal on Information Systems in Developing Countries, 18(1), 1-24.

Nwankwo, O. F. (2014). Impact of Corruption on Economic Growth in Nigeria. Mediterranean Journal of Social Sciences, 5(6), 165-169.

Ogunro, K. V., \& Tolu, L. (2012). Combating Corruption in Nigeria. International Journal of Academic Research in Economics and Management Sciences, 1(4), 226-244.

Oye, N. D. (2013). Reducing Corruption in African Developing Countries: The Relevance of E-Governance. Greener Journal of Social Sciences, 3(1), 006-013.

Shatne, K. (2001). Constituent Relationship Management Systems: A Primer for Public Managers. Government Finance Review, 17(2).

Symonds, M. (2000). Government and the Internet: The Next Revolution. Economist, 355(8176).

World Bank. (1997). World Development Report 1997. Retrieved February 2, 2018, from http://web.worldbank.org 